\title{
İslâm Bilim Tarihi: İslâm Coğrafyasının Bilim Mirası Üzerine Konuşmalar
}

Ahmed Cebbar, çev. Lütfi Fevzi Topaçoğlu

İstanbul: Küre Yayınları, 2016, 272 sayfa.

ISBN 9786059125307

İslâm bilim tarihi ya da İslâm tıp tarihi gibi bu başlı̆̆ın daha spesifik türlerine ve İslâm bilim tarihi yazıcılığına hayli uzun bir zamandır Batı akademyasının dikkatle eğildiği bilinmektedir. Farklı teoriler ve söylemler çerçevesinde ortaya çıkmış devâsâ literatürden sonra Fuat Sezgin, George Saliba ve Rüşdî Râş̧id gibi bilim tarihçilerinin öncülügüünde İslâm bilim tarihi çalışmaları farklı bir evreye girmiştir. İlim dünyasının İslâm bilim tarihine yönelik algısının değişmesinde merhum Fuat Sezgin'in olağanüstü gayretlerini ve özellikle onun Wissenschaft und Technik im Islam (İslâm'da Bilim ve Teknik, I-V, İstanbul: İstanbul Büyükşehir Belediyesi Kültür A.Ş. Yayınları, 2008) ile muhallet eseri Geschichte des arabischen Schrifttums'u, yaygın olarak bilinen kısaltmasıyla $G A S_{1}^{\prime}$ zikretmek gerekir. Toplam on yedi cilt olan $G A S^{\prime}$ in ilk cildinin Türkçe’ye çevrildiğini de hatırlatalım (Arap-İslâm Bilimleri Tarihi, I, İstanbul: Prof.Dr. Fuat Sezgin İslam Bilim Tarihi Araştırmaları Vakfı Yayınları, 2015). Diğer yandan daha mütevazi eserlerin de alana olan katkısı yadsınamaz. Rüşdî Râşid'in editörlügünde yayımlanan üç ciltlik Encyclopedia of History of the Islamic Sciences (London\&New York: Routledge, 1996) ile George Salibanın Islamic Science and the Making of the European Renaissance (Cambridge: The MIT Press, 2007) adlı eserini de bu halkaya ekleyebiliriz. Türkçe'de ise İslâm bilim tarihinin özellikle Osmanlı dönemi için IRCICA tarafından yayımlanmış literatür çalışmaları büyük bir hizmet olarak görülmeli, ayrıca İhsan Fazlıŏglu’nun birçok çalışması bu alanda yapılan yöntem yanlışlarına, eksikliklere dikkat çekmesi açısından önemli olmalarının ötesinde bilhassa Seçluklu ve Osmanlı bilim mirasının bilinmeyen mümtaz şahsiyetlerini ve eserlerini ilim dünyasının dikkatlerine sunmuş, kavram ve teori düzeyinde yeni ufuklar açmıştır. Nihayet İslâm Düşünce Atlası'nın (ed. İbrahim Halil Üçer, I-III, Konya: Konya Büyükşehir Belediyesi Kültür Yayınları, 2017) İslâm düşünce ve ilim tarihinin dönemlendirilmesi üzerine yaptığı öneriler, coğrafyalar arasındaki etkileşimler ve âlimlerin ilişkilerine yönelen bakışı başta olmak üzere birçok açıdan heyecan verici bir çalışma olduğunu ifade etmek gerekir.

Değerlendirmemize konu olan eserin yukarıda zikredilen birçok örnekle hem hacim ve tür hem de uyandırdığı etki bakımından kıyaslanması doğru 
olmaz. Buna karşın İslâm bilim tarihi yazıcılı̆̆ında dikkate değer yanlarının olduğunu söyleyebiliriz. Orijinal adı Une sistoire de la science arabe: Introduction à la connaissance du patrimoine scientifique des pays d'islam olan eser, Jean Rosmorduc'un Ahmed Cebbar ile yaptığı söyleşilerden derlenmiştir (Paris: Le Seuil, 2001).

Cezayir asıllı olan Prof. Ahmed Cebbar, Lille Teknoloji ve Bilimler Üniversitesinde matematik tarihi alanında dersler vermektedir. Matematikçi ve matematik tarihçisi olan Cebbar’n bilim tarihi alanında çok sayıda makalesi ve çeşitli çalışmaları bulunmakta, ayrıca CNRS laboratuvarı bünyesinde de yer almaktadır. L'oeuvre algébrique d'Al-Khayyam, Histoire d'algorithmes: Du caillou à la puce, La vie et loeuvre d'Ibn al-Banna al-Murrakushi: un essai bio-bibliographique, Les sciences arabes en Afrique: Mathématiques et astronomie (IXe-XI$X^{e}$ siècles), Ulemâü'l-hadâreti'l-Arabiyyeti'l-İslâmiyye ve müsâhemâtühüm adlı eserleri kaleme almıştır. Bu çalışmada yer alan soruları hazırlayan ve Ahmed Cebbar'a yönelten Jean Rosmorduc ise Universite de Bretagne Occidentale'de fizik ve bilim tarihi dersleri vermektedir. La polarisation rotatoire naturelle de la structure de la lumière à celle des molécules, Matiere et energie, Histoire de la physique: La formation de la phsique classique gibi eserleri vardır.

Toplam dokuz bölüm olarak tasarlanan eserde içindekilerden hemen önce kronolojik bir çizelge ile yazar siyasî bir şema oluşturmuştur. Böylece İslâm imparatorluğu şeklinde adlandırarak genelleştirdiği devletlerin hâkim olduğu bölgeler gösterilmiştir. Bu çizelge konu edinilen coğrafyayı belirlemek adına önemlidir. Kitapta yer alan bölümlerin dizilimi İslâm dünyasında yapılan bilimler tasnifine aykırı değildir. Ahmed Cebbar’ın kaleme aldığı İslâm Bilim Tarihi Jean Rosmorduc'un sorularının ekseninde yazılması sebebiyle farklı bir bakış açısı oluşturmuştur. İslâm dünyasında ortaya konulan bilimsel faaliyetlerin Batılılar tarafından merak edilen kısımları ortaya çıkarması açısından dikkat çekicidir.

Yazar kitabın giriş kısmında İslâm dünyasında özellikle IX ve XV. yüzyıllar arasında yapılan çalışmaların bilinmemesinin veya sadece Antik Yunan ve Aydınlanma çağı olarak adlandırılan Batı bilimine aracı olan basit bir tercüme hareketi olarak değerlendirilmesinin büyük bir haksızlık olduğu gerçeğini ortaya koymuştur. Girişte böyle önemli bir iddianın dile getirilmesi kitabın bu anlamda ele alınan temel argümanını da belirlemiştir. Böylece bilim tarihi literatüründe var olan muazzam kopukluk giderilmeye çalışılmıştır.

$\mathrm{Bu}$ eseri kaleme alırken yazar yalın bir dil kullanacağını ve böylece herhangi bir uzmanlığı olmayan kimselerce de kitabın anlaşılabileceği garantisini vermiştir. Ayrıca İslâm dünyasından bilime katkı sağlayan birçok bilginin 
çalışmalarının bu kitapta yer bulacağını okuyucuya bildirmiştir. Ancak yazar, eldeki verilerin azlığını gerekçe göstererek kitapta ayrıntılara temas etmeyeceğini açıklamıştır. Oysa verilerin birçoğu adı geçen İslâm düşünürlerinin günümüze kadar ulaşan eserlerinde bizzat bulunmaktadır. Bu bağlamda öne sürdüğü gerekçe çok kabul görmeyecektir. Fakat bu eksikliği yazarın kendisi de görmüş olmalı ki eserin kapsamının genişletilmesi gerektiğini belirtmiştir. Özellikle elde edilecek yeni katkılarla daha zenginleşecek yeni bir eserin kaleme alınabileceğini öne sürmüştür. Bunun yanı sıra kitabın ağır olmaması amacıyla söyleşi şeklinde kaleme alındığına da yer vermiştir. Kitabın bu şekilde kaleme alınmasının gerekçeleri aşağıdaki şekilde sıralanmıştır:

1. Batılı bir düşünürün perspektifinden İslâm bilim dünyası hakkında merak edilenler ortaya konulmuştur.

2. Her düzeyden okuyucuya hitap etmesine olanak tanımıştır.

3. Herkes tarafından bilinmeyen kişilere ve yaptıklarına da yer verilerek göz ardı edilenlere ş̧ık tutmuştur.

Yazar giriş kısmını tamamladıktan sonra "İslâm İmparatorluğunun Ortaya Çıkışı ve Büyümesi” olarak adlandırdığı ilk bölüme yer vermiştir. Elbette bu bölümde İslâm’ın doğup büyüdüğü coğrafyaya kapsamlı bir biçimde yer vermiştir. Bu bölümde Ortadoğu coğrafyasında kurulan devletlerin tek tek değil de hepsini içine alan bir kavramla adlandırılmasının hem olumlu hem de olumsuz sonuçlar doğurduğunu söylemek gerekmektedir. Şöyle ki; İslâm imparatorluğu kavramı ile yapılan çalışmalar bir medeniyete mal edilmiştir, bu yönü olumlu görünse de sonraki dönemlerde iyi niyetli bir kullanım olmadığı ortaya çıkmıştır. Zira kavram kullanımının yanlış olması bu dönemde yapılan bilimsel faaliyetlerin tamamının Arap bilimi olarak adlandırılmasına zemin hazırlamış ve İslâm bilim tarihine yönelik eski yaklaşımın farklı bir boyutu olarak tezahür etmiştir.

Kitabın içeriğine tekrar dönülecek olursa müslümanların yayıldıkları bölgede muhatapları hakkında bilgi verilmiştir. Bununla birlikte İslâm’ın ilk yüzyıllarında yer alan İslâm peygamberi ve dört halifenin hüküm sürdügü dönemler tanıtılmıştır. Hemen ardından büyük iki devlet olan Emevîler'in ve Abbâsîler'in İslâm medeniyetine katkıları üzerinde durulmuştur. Yazarın bu bölümü İslâm imparatorluğu olarak adlandırmasına rağmen aynı bölümün başka bir alt başlı̆̆ında şehir devleti kavramını kullanması veya yukarıda adı geçen iki devletin tanıtımı çelişki oluşturmuştur. İslâm’ın doğuşundan itibaren böyle bir adlandırmaya gitmesi isimlendirmede hata yapıldığ olmadığını göstermiştir. Siyasî-sosyal ve dinî gelişmeler ardışık bir biçimde aktarılarak bölüm tamamlanmıştır. 
“İslâm Ülkelerinde Bilim” olarak adlandırdığ bu bölümde kitabın temel amacının ortaya konulacağı kısma geçilmiştir. Burada İslâm’ın ortaya çıktığı ortamda bilimsel faaliyetlerin nasıl olduğu sorusu akla ilk gelen soru olmuştur. Bu bağlamda "Kur'an’ın nasıl kaleme alındı?", "Araştırma yapmaya uygun ortam var mıydı?” gibi sorular yöneltilmiştir. Ayrıca kutsal metinlerin bilim ile ilişkisi de sorgulanmıştır. İslâm dininin bilimsel çalışmalara nasıl baktı$\breve{g}_{1}$ cevap arayan bir diğer soru olmuştur. Bu sorular hemen hemen her şarkiyatçının aklına gelen ilk sorulardır. Ancak bununla birlikte Kur'an'a dayalı felsefenin Pisagorcu (Pythagoras) görüşler içerip içermediği gibi sorular da yer bulmuştur. İslâm dünyasında yapılan bilimsel çalışmaların dinî ihtiyaçlar neticesinde şekillenmiş olmasına rağmen; Kur’an’ı referans olarak kullanan herhangi bir düşünürün olmadığg görüşü yazar tarafından örnekleri ile savunulmuştur. Sorularla İslâm biliminden ziyade İslâm’nn bilime bakış açısı sorgulanmıştır. Yazar da bunu farketmiş olmalı ki bağlamı İslâm bilginlerinin kullandığı yöntemin dinî referanslardan bağımsızlı̆̆ına yönlendirmiştir. Ayrıca yapılan çalışmaların Pisagorculuk'la ilişkisi olup olmadığ üzerinde durularak yapılanların ne seviyede mistik veya mitsel öge barındırdığı tespit edilmeye çalışılmıștır. Ancak verilen yanıtlar tatmin edici seviyede olmasa da yapılanların göz kamaştırıcı oldukları belirtilmiştir. Nitekim dönemin şartları dikkate alındığında yapılanlar hiç de küçümsenecek seviyede değil, hatta dönemi aşacak düzeydedir.

Söyleşiyi yapan Rosmorduc, İslâm dünyasında yapılan çalışmaların Ortaçağ Hıristiyanlığı ile karşılaştırılmasına yönelik sorular da geliştirmiştir. Böylece din ve bilim arasındaki ilişkinin yönü belirlenmeye çalışılmıştır. Fakat skolastik dünya ile İslâm biliminin en parlak dönemini karşılaştırmanın pek de yerinde olduğu söylenemez. Bu bölümde vurgulanan konulardan bir diğeri siyasi erkin bilimi ne düzeyde teşvik ettiği veya desteklediğidir. İslâm devletlerinin önemli devlet adamlarının yardımlarıyla bilimsel faaliyetlerin yönlendirildiği belirtilmiştir. Devlet adamları ve bilim adamlarının adlarına yer verilerek neler yapıldığı ortaya konulmaya çalışılmıştır. Böylece yazar dönemin atmosferini de tasvir etmiştir. Bilim dilinin gelişim düzeylerine de yer verilmiştir. Bu bağlamda Arapçảnın bölgede konuşulan diğer dillerle kıyası yapılmıştır.

Bilimin kümülatif ilerlediği savını da destekler nitelikte olan üçüncü bölüm "Miraslar ve Bilgi Alışverişleri” şeklinde adlandırılmıştır. Bu bölümde Antik Yunan’n gerçek mirasçısının Roma ve Bizans olmasına rağmen İslâm üzerinden devam etmesinin gerekçeleri üzerinde durulmuştur. İslâm dünyasının bilim yaparken başvurduğu kaynaklar belirtilmiştir. Bunun yalnızca tercüme düzeyinde kalmadığı anlatılmıştır, fakat tercüme hareketlerinin 
İslâm bilim dünyasında daha geniş yer tuttuğu izlenimi bu eserde de sürdürülmüştür. İlk bilimsel kitapların hangi dönemde ortaya çıtığı kaleme alınmıştır. Ayrıca İslâm dünyasının miras olarak kullandıklarının büyük bir kısmının Antik Yunan'dan alınanlar olduğu da ifade edilmiştir. Doğu dünyasından yani Hint, Çin ve Pers'ten alınanların daha küçük bir orana sahip olduğu belirtilmiştir. Ancak bilimsel çalışmaları mirasın aktarımı olarak ele alan yazar çok küçük bir kısım olsa da Latince'ye çevrilen eserlere yer vermiştir. Bu bölümden hemen sonra İslâm bilginlerinin çalışma yaptığı alanlara yönelik müstakil bölümler kaleme almıştır. Bu bölümde diğer bölümlerde olan eksiklik sürmektedir. Zira tercüme faaliyetlerinin Antik Yunan eserlerinde yoğunlaşmasının gerekçesi olarak diğer medeniyetlerin eksikliği değil, coğrafi şartlar gösterilmiştir.

Altı yüzyılda birçok kişinin farklı alanlarda yaptıklarının ortaya konulması oldukça zor bir iştir. Üstelik hacimsel anlamda sınırlandırmanın olması yazarın kendisini rahatça ifade etme imkanını ortadan kaldırmıştır. Buna rağmen yapılan çalışmaları sınıflandırarak ele almıştır. Okuyucunun haberdar olması veya genel bilgilendirilmesi düşünüldüğünde yazarın yaklaşımı önemlidir.

"Astronomi" adlı bölümde hem bu alanda daha önce yapılmış çalışmaların İslâm dünyasına geçişine hem de İslâm bilginlerinin yapmış olduğu özgün çalışmalara yer verilmiştir. Bu alanda adı öne çıkan düşünürlere ve eserlerine de değinilmiştir. Bir diğer bölüm "Matematik" ile ilgilidir. Matematik, İslâm dünyasında da önemli çalışmaların yapıldığı bir alandır. Burada da bir önceki bölümde olduğu gibi yapılan katkılar hem görseller hem de örnekler yardımıyla sunulmuştur. Birçok kimse tarafından bilinen isimlerin yanı sıra yaptıkları bize birinci kanallar aracılığı ile ulaşmayan isimlere de yer verilmiştir. "Fizik" ve "Yer Bilimleri ve Canlı Bilimleri" olarak adlandırılan bölümlerde de edinilen bilimsel mirasın üzerine eklenenler verilmeye çalışılmıştır.

"Anatomi ve Tip" bölümünde Hipokrat ve Galen'den sonra en önemli tabip ve hekim olan İbn Sînẩnın bu alanda yaptığı çalışmalara yer verilmiştir. Bu bölümde İslâm bilim dünyasının çalışmalarına ek olarak yapılan hastaneler, dârüşşifalar ve kullanılan tedavi yöntemlerine de temas edilmiştir. "Kimya" bölümünde de diğer bölümlerde yapılanlara ilâveten kimyanın simyadan ayrışması serüveni üzerinde durulmuştur. Her bölümde kaynakça ayrıca belirtilmiştir.

Sonuç bölümünde yazar bir özeleştiride bulunarak iki çelişkili izlenim oluşturduğunu ifade etmiştir. Ona göre ilk izlenim İslâm medeniyetinin bilim tarihine katkısını sunma noktasında, ikincisi ise göreli bir tatminsizlik 
şeklinde olmuştur. Yazar ortaya koyduğu perspektifle eserin yayımlandığ yıllarda Batı'da İslâm medeniyetine yapılan haksızlığın nispeten giderildiğine inanmaktadır. Cebbar özellikle sömürge zihniyetinin düşüncedeki yansımalarının izâle edilmesine katkı sağlaması amacıyla kaleme alınan bu eserin büyük oranda hedefine ulaştığını belirtmiştir. Ancak Ahmed Cebbar’ın uzmanlık alanının matematik olması kendi çalışma sahasının dışında yeterli düzeyde bilgiye erişemediğinden yakınmasına sebep olmuştur. Yazarın bir otokritik yaparak eserinin eksik yanına işaret etmesi kabule şayan olsa da birtakım eleştirilere mâruz kalmasına da engel değildir. Meselâ kitabı, başta uzmanı olduğu alanlara hasretmesi ya da belli alanları o sahanın önde gelen isimleriyle ortak hazırlaması düşünülebilirdi.

Bu çalışma ile dönemin hem sosyopolitik yapısı hem de yapılan bilimsel çalışmalar bütüncül bir şekilde ortaya konulmuştur. Böylece bilim tarihinin insanlığın ortak mirası olduğu gerçekliği bir defa daha serdedilmiştir. Bunun Batılı bir bilim tarihçisinin konuya dair zihninde beliren sorularla yapılması ayrıca farklı bir perspektifin ortaya çıkmasını sağlamıştır. Bütün bu özelliklerine ilâveten akıcı ve etkin bir üslûpla yazılan kitap okurun istifade edebileceği bir çalışmadır.

Canan Ağyürek, Doktora Öğrencisi İstanbul Medeniyet Üniversitesi

ORCID 0000-0002-4104-5008 DOI 10.26570/isad.517444 